\title{
PERANCANGAN CERITA DAN KARAKTER BERTEMAKAN DEPRESI DALAM ANIMASI "AGONY"
}

\author{
Florencia Irena $^{1)}$ Arik kurnianto ${ }^{2)}$ \\ School of Design-Animation, Binus University \\ florenciairena@binus.ac.id ${ }^{1)}$ arikkurnia@binus.ac.id ${ }^{2)}$
}

\begin{abstract}
Depression is as old as the human race, and not many people realize its presence. It is difficult for someone with depression to explain their experience. Depression -whatever the cause, can disturb someones life mentally or physically. Animation can be one of the media that able to visually represent and explain depression's experiences and still entertain the viewers. To create that kind of visuals, great and solid idea/concept are needed. Of course storyline is also put a big impact on a film. In this research, writer did kinds of study with qualitative methodology. This research also leads to design aspect, especially for characters and environments. Result
\end{abstract}

Keywords: depression, short animation,suicide, visualization 


\section{PENDAHULUAN}

Depresi sama tuanya dengan ras manusia, tak jarang orang tidak menyadari kehadirannya. Terkadang, tanpa alasan yang pasti kita merasa sedih yang tak terbendung. Dunia menjadi abu-abu dan merasakan pahit di mulut. Kita mencoba untuk menggapai pertolongan namun seringkali menemukan diri kita selalu sendiri. Untuk beberapa orang, depresi tidak lebih dari sesuatu yang terjadi sekejap, atau dapat ditangani dengan pemikiran rasional dan tindakan praktikal. Namun bagi sebagian dari kita, pengalaman ini menjadi hantu yang tanpa diundang datang di setiap kesempatan, atau malah lebih buruk, penjara dengan dinding yang kasat mata namun mustahil untuk ditembus (Rowe, 2003: 7)

Dalam berbagai kasus, orang yang yang menglami depresi sering kali tidak menyadari posisi dirinya pada saat itu. Terkadang depresi dianggap sebagai mood swing biasa yang nantinya akan hilang dengan sendirinya. Namun ketika seseorang pada akhirya sadar, ia menemukan dirinya sudah pada keadaan yang sulit. Belum lagi terdapat stigma di masyarakat akan "psikolog" atau topik lain yang menyinggung masalah kejiwaan. Hal ini menjadikan seseorang dengan masalah demikian lebih cenderung untuk self diagnose dan menarik diri.

Depresi merupakan sebuah perasaan rumit yang hampir tidak dapat diungkapkan secara langsung begitu saja lewat kata-kata. Mengatakan bahwa seseorang depresi, sedih atau terpuruk dapat diartikan orang lain sebagai hari buruk semata. Terkadang seseorang merasa begitu kacau hingga mustahil untuk tahu harus mulai cerita dari mana. Jadi kebanyakan memilih untuk diam.

Sadar akan hal itu, penulis terinspirasi untuk membuat cerita mengenai depresi dan mengangkatnya menjadi sebuah animasi pendek. Diharapkan pesan yang dimaksud dapat lebih maksimal diterima oleh penonton dengan penyampaian secara visual. Penulis berharap dengan penelitian ini penulis dapat memahami lebih mengenai apa itu depresi dengan mencari data yang dapat dianggap valid lewat wawancara dengan narasumber terkait seperti psikolog. Selain itu penelitian ini juga berupa mengkaji film, baik animasi maupun realshot yang memiliki tema atau story telling yang serupa sehingga dapat menemukan bagaimana menghasilkan sebuah cerita yang tidak hanya menarik dari segi konsep, namun juga dengan cara penyampaian yang tidak literal sehingga memicu ketertarikan penonton untuk ikut serta secara mental dalam jalannya cerita.

\section{Kajian Literatur}

Penulis melakukan tinjauan pustaka serta tinjauan film animasi untuk meneliti dari segi tema yakni depresi, dari segi penyampaian alur cerita dan tinjauan visual berupa karakter desain.

\section{Teori Unsur Cerita}

Di dalam sebuah cerita, tentu saja terdapat berbagai macam aspek yang saling mendukung sehingga membuat cerita menjadi satu kesatuan yang memiliki alur, pesan dan dapat dinikmati oleh orang lain. Namun pada dasarnya, dalam pembuatan sebuah cerita terdapat 2 unsur yang mempengaruhi hasil akhir cerita tersebut, yakni unsur intrinsik dan ekstrinsik. Unsur intrinsik merupakan unsur yang terdapat dalam cerita itu sendiri yang kemudian membangun cerita menjadi sedemikian rupa. Unsur intrinsik meliputi tokoh, latar (settings), alur, sudut pandang (point of view), gaya bahasa, tema dan amanat. Sedangkan unsur ekstrinsik merupakan unsur-unsur yang terdapat diluar sebuah karya yang secara tidak langsung mempengaruhi pembuatan cerita seperti kondisi masyarakat pada saat itu, pandangan hidup pengarang atau 
bahkan pengalaman dan latar belakang pengarang itu sendiri.

Desain Karakter

Dalam animasi, elemen apapun yang dapat terbayangkan, nyata ataupun imaji dapan dibuat menjadi sebuah karakter. Di samping membuka kemungkinan untuk fantasi, bekerja dengan menggunakan karakter imaji juga dapat memberikan keuntungan, seperti karakter tersebut dapat mengatasi materi yang memiliki potensi sensitif. Sebagai contoh, akan sangat sulit untuk membuat film yang dapat dinikmati keluarga jika mengangkat cerita mengenai seorang ayah yang anaknya diculik dan disekap. Ketika cerita tersebut terdengar seperti cerita yang tidak dapat dinikmati anak, namun faktanya itu adalah plot dasar cerita Finding Nemo, film yang sangat baik bahkan untuk anak kecil.Terdapat beberapa aspek penting dalam mendesain sebuah karakter yakni Style/Gaya, proporsi, perilaku, siluet dan Detil.

\section{Data Wawancara Psikolog}

Penulis melakukan wawancara dengan seorang dosen psikolog yakni Antonina Pantja Juni Wulandari, S.Sos., M.Psi untuk memenuhi data-data mengenai karakteristik dan perilaku orang depresi. Beliau merupakan seorang sekertaris jurusan Psikologi di universitas Bina Nusantara.

Berdasarkan hasil dari wawancara dengan ibu Juni, penulis mendapatkan data sebagai berikut:

1. Penyebab umum depresi adalah ketidaksesuaian harapan dengan kenyataan.

2. Depresi dapat disebabkan oleh berbagai macam faktor termasuk trauma dalam keluarga sekalipun.

3. Depresi dapat mempengaruhi kehidupan seseorang baik secara fisik maupun mental.
4. Kecenderungan seorang penderita depresi adalah menarik diri dari lingkungan sekitarnya, sulit mempercayai orang untuk berbagi ceritanya. Sehingga membutuhkan waktu yang lama dan dengan perlahan untuk menggali orang tersebut.

5. Ciri umum orang yang depresi adalah sulit tidur karena selalu merasa cemas dan tidak nyaman dengan dirinya. Sehingga yang paling terlihat dengan jelas adalah wajah yang selalu lelah.

\section{Ide/Cerita}

Untuk membuat sebuah cerita yang menarik dibutuhkan ide atau tema yang menarik pula. Namun hal itu kembali lagi kepada cara sang penulis mengembangkan sebuah ide dan kemudian mengeksekusinya menjadi sebuah kesatuan cerita utuh. Didalamnya, cerita memiliki struktur awalan, tengah dan akhir yang merupakan lapisan utama dari keseluruhan cerita. Akan sulit untuk memahami apa yang terjadi dalam sebuah cerita tanpa ketiga bagian ini. Namun arah cerita membutuhkan lebih dari ketiga elemen sederhana ini (Beane,2012). Untuk meningkatkan ketertarian sebuah cerita, dibutuhkan adanya story arc atau alur cerita yang tidak linear. Namun bukan berarti menyalahkan sebuah cerita dengan alur linear. Hanya saja kerika struktur tersebut sudah terlalu lama dipakai dalam berbagai cerita sehingga menghasilkan karya yang serupa.

Seperti yang dijabarkan Beane pada bukunya Animation Essentials (2012), lapisan selanjutnya pada arah cerita adalah ketegangan atau level kegembiraan. Sebagai contoh sederhana, sebuah film khasnya dimulai dengan pembukaan yang menggairahkan/ menarik untuk mendapatkan perhatian penonton, dan menarik mereka untuk mau menonton lebih jauh. Selanjutnya ketegangan diredakan dan kemudian 
dibangun kembali secara bertahap, dan semakin besar setiap waktu sampai pada akhirnya pertarungan final atau konfrontasi. Terakhir, ketegangan kembali diredakan lagi untuk penonton tenang diakhir Prinsip cerita yang baik, yang diungkapkan dalam buku 3D Animation Essentials oleh Andy Beane (2012: 112)

1. Gunakan empati dan bukan simpati. Empati adalah kemampuan untuk mengerti perasaan orang lain dan ikut merasakan apa yang dirasakan oleh orang lain. Simpati, disisi lain, adalah mengerti akan perasaan orang lain, namun pengamat tidak ikut merasakan perasaan yang sama seperti empati. Empati menciptakan koneksi yang lebih kuat pada sebuah karakter dan mampu membuat penonton merasa terhubung dengan cerita anda dan bukannya sekadar mengerti cerita anda. Anda harus selalu mencoba untuk menciptakan karakter yang memiliki hubungan dalam berbagai cara. Hal ini tidak mengartikan karakter anda harus membosankan, orang normal, namun anda harus mencari cara untuk membuat mereka memiliki sifat yang dapat berkenaan dengan penonton. Karakter anda dapat memiliki sifat luar biasa sekalipun, namun jika anda dapat mencari sifat yang relevan dengan penonton maka akan memungkinkan sebuah ikatan.

2. Perlihatkan, bukan memberitahu. Walaupun anda menulis novel atau skenario film, anda mau menciptakan gambar pada pikiran penonton. Anda tidak mau hanya menceritakan kepada penonton apa yang akan terjadi dan bagaimana perasaan karakter. Anda mau memperlihatkan kepada mereka. Gunakan tindakan, pemikiran, dialog dan perasaan untuk membimbing penonton melewati cerita.
3. Hukum tiga, konsep ini digunakan dalam penulisan, film, animasi, komedi dan periklanan. Ungkapan bahwa perkataan, benda atau situasi menjadi lebih lucu atau dapat diingat dengan baik jika dilakukan dalam 3 kali.

Semiotika Dalam Meningkatkan Kedalaman Cerita Pada Animasi

Untuk membuat sebuah film yang dapat menyampaikan pesan, dibutuhkan aspek-aspek seperti tema, plot, struktur cerita, karakter, setting (latar belakang), style (gaya) dan tone (suasana). Namun tidak cukup hanya dengan memunculkan aspek tersebut saja, hal yang terpenting adalah bagaimana penonton bereaksi atau menanggapi sebuah film baik dari segi cerita, atau secara keseluruhan. Jika film memiliki elemen dan pengembangan cerita yang baik namun gagal dalam menyampaikannya dan tidak dapat membangun hubungan dengan penonton, maka tujuan film untuk menyampaikan pesan tidak akan terpenuhi. Namun penyampaian pesan pada film secara gamblang akan lebih memungkinkan penonton untuk cepat bosan, hal ini dikarenakan tidak ada yang perlu diproses oleh penonton untuk mendapatkan sebuah informasi cerita sehingga tidak timbul rasa ketertarikan atau "rangsangan" terhadap film. Maka dari itu film dengan perumpamaan atau simbol dinilai lebih "menarik" bagi penonton.

Respon baik seseorang terhadap simbol ini pada dasarnya berasal dari efek saraf manusia secara alami. Menurut penelitian oleh Human Computer Interface (HCI), manusia memiliki reaksi yang tidak dapat dikontrol jika berinteraksi dengan sebuah sistem. Ashby et al (1999) mengatakan bahwa peningkatan kemampuan untuk menyelesaikan masalah berhubungan dengan efek kimia neurotransmiter yang 
disebut dopamine. Dopamine inilah yang dilepaskan ketika seseorang merasa bahagia, senang atau puas. Dopamine juga dilepaskan ketika seseorang mendapatkan perasaan/ reward tak terduga. Holleram dann Shulz (1998) juga menjelaskan bagaimana level dopamine berbeda berdasarkan prediksi dari sebuah reward. Reward yang diluar dugaan akan menghasilkan dopamine paling banyak dan memberikan rasa puas paling besar. (Hodgkinson, 2007:20)

Jika kita mengaitkan efek saraf manusia tersebut dengan simbolisme pada film, itu berarti ketika seseorang menonton sebuah film dengan alur cerita atau simbolisme yang tidak terduga maka akan menghasilkan reward atau kepuasan yang baik bagi penonton. Namun pemberian simbol yang dimaksud bukanlah simbol rumit yang tidak dapat dipecahkan oleh penonton, melainkan simbol yang cerdik, dapat dipecahkan dan dapat menstimulasi penonton (Hodgkinson, 2012). Karena pemirsa dibutuhkan untuk memecahkan simbol, oleh karena itu solusi yang dihasilkan merupakan bagian dari proses pikir kreatif pemirsa. Terlepas dari menerima peningkatan reaksi kimia emosional -yang dijabarkan diatas, ada kemungkinan lebih besar untuk pesan dari film tetap tinggal pada penonton bahkan setelah film selesai. (Hodgkinson, 2012:4).

\section{Fisiognomi}

Fisiognomi, berasal dari kata inggris physiognomy, yang merupakan singkatan dari fisiologi dan anatomi. Fisiologi banyak dikaji ilmuwan, seperti kedokteran dan ilmu psikologi. (Amda \& Fitriyani, 2016).

Sejak zaman Aristoteles, para ilmuwan dan filsuf telah merasa takjub dengan hubungan antara ciri fisikk individu dengan watak kepribadian antara struktur ciri fisik seseorang dengan perilakunya. Fisiognomi, yakni kajian mengenai wajah, telah berusia sekitar 2.700 tahun. Ilmu ini telah menarik perhatian para ilmuwan selama bertahuntahun. (Tickle,2003/2015)

Dengan menggunakan prinsip ilmiah yang sudah mapan, Edwar Jones seorang hakim Los Angeles pada tahun 1930-an memperhatikan 200 ciri waja yang berbeda dan kemudian menyempitkannya menjadi 68 ciri. Kajiannya mencakup tangan dan proporsi tubuh. Hasil penelitiannya mempunyai akurasi sebesar $92 \%$ dalam menentukan profil kepribadian. Sistem yang dihasilkan menggantikan metode-metode yang terlebih dahulu muncul mengenai pengkajian terhadap ciri manusia. Berkat Hakim Jones, fisiognomi "baru" menjadi pendekatan ilmiah terhadap pembacaan wajah. (Tickle,2003/2015)

Seperti yang kita ketahui bahwa bentuk fisik dan kepribadian juga merupakan turunan dari faktor genetik. Dan hal ini pula lah yang diungkapkan oleh pada ahli fisiognomi. Seperti pada buku cara cepat membaca wajah karya Naomi R.Tickle (2003/2015), Dari sudut pandang para ahli fisionogmi, kecenderungan diwarsikan oleh orangtua, namun demikian, lingkungan rumah dan kondisi pribadi seseorang bisa menjadi pengaruh utama yang meningkatkan atau mengubah kecenderungan tersebut. Hal ini berlaku untuk watak-watak positif maupun negatif.

\section{Teori Behaviorisme}

Secara umum, teori behaviorisme memfokuskan kepada kajian tingkah laku yang dapat dilihat dan diukur. Teori behaviorisme memandang pemikiran sebagai "kotak hitam" yang bereaksi terhadap rangsangan. (Aris et al, 2004 : 42)

Terdapat beberapa tokoh besar yang berperan pada masa perkembangan teori behaviorisme yakni Ivan Pavlov, John B. Watson, dan B.F. Skinner. Ivan 
Pavlov lebih dulu mengemukakan teori mengenai classical conditioning yakni keadaan dimana stimulus yang tidak disengaja akan menciptakan respon yang tidak disengaja.

Pada percobaannya, Pavlov menyatakan bahwa terdapat hubungan antar stimulus (rangsangan) dengan respon. Pavlov melakukan menerapkan teorinya ini pada anjingnya sendiri yakni dengan lonceng dan makanan, dimana lonceng berperan sebagai perangsang yang disebut Pavlov sebagai conditioned stimulus(CS) karena efeknya yang bergantung pada asosiasi subjek terhadap objek. Sedangkan makanan disebut dengan unconditioned stimulus (US) karena efeknya yang tidak bergantung pada pengalaman sebelumnya. Dengan begitu, respon terhadap conditioned stimulus disebut dengan conditioned response(CR) dan respon terhadap unconditioned stimulus disebut unconditioned respond(UR). Makanan sebagai US akan menghasilkan saliva pada anjing yang dianggap sebagai UR. Selanjutnya, lonceng sebgai CS dibunyikan, maka tidak menghasilkan respon apa-apa terhadap anjing. Namun ketika lonceng diikuti dengan makanan, maka akan menghasilkan saliva pada anjing. Dan jika hal ini dilakukan berulang-ulang maka akan ada proses pembelajaran pada anjing yakni ketika lonceng dibunyikan akan ada makanan dan anjing akan menghasilkan saliva. Dengan begitu ketika lonceng dibunyikan, walaupun tanpa makanan, anjing akan tetap menghasilkan saliva karena adanya kebiasaan yang mana kemudian disebut dengan behaviorisme oleh Watson.

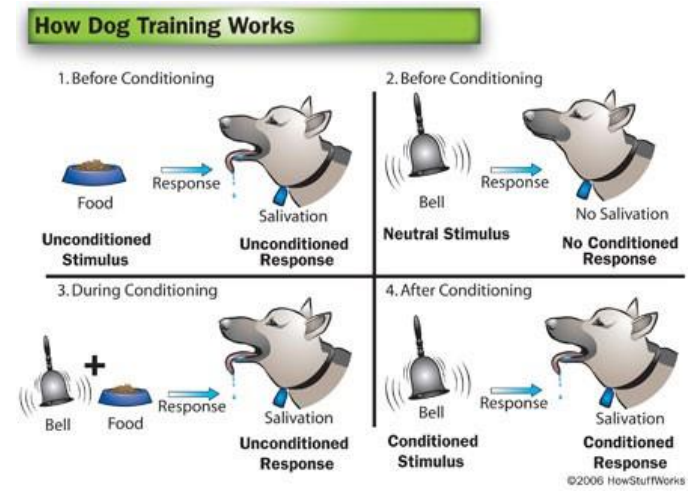

Gambar 2.1 Uji Coba Behaviorisme Pada Anjing

Selanjutnya, Watson kemudian mengaplikasikan classical conditioning ini pada manusia dan dikenal sebagai percobaan little albert. Dimana watson menempatkan seorang anak kecil (Albert) dan seekor tikus putih. Albert pada mulanya menyentuh tikus putih dan tidak terjadi apa-apa. Kemudian Watson memberikan sebuah bunyi yang kencang setiap saat Albert menyentuh tikus putih. Albert takut dengan bunyi kencang tersebut dan kemudian menjadi takut dengan tikus putih.

Dari penjabaran diatas dapat disimpulkan bahwa pada dasarnya manusia dan binatang memiliki apa yang disebut dengan proses pembelajaran. Perangsang dan respon berperan penting sebagai salah satu elemen pembelajaran pada manusia maupun hewan, dan jika sebuah tindakan yang melibatkan perangsang (stimulus) dan respon dilakukan secara berulang-ulang akan menimbulkan adanya proses pembelajaran dan menghasilkan sebuah perilaku yang dapat dilihat dan diukur, kegiatan tersebutlah yang dinamakan dengan behaviorisme. Teori ini telah banyak diterapkan secara tidak sadar oleh manusia. Sebagai contoh, seorang anak selalu dipukul ketika melakukan kesalahan, seekor singa sirkus akan dicambuk ketika tidak mengikuti perintah pawang atau seorang mantan prajurit yang menjadi takut ketika mendengar suara kencang. 


\section{Depresi}

Seseorang dengan depresi biasanya terlihat bimbang, takut dan tidak stabil yang disebut peneliti dengan sebutan "nervous breakdown" atau "gangguan saraf". Orang dengan depresi yang akut sering kali merasakan kesedihan hampir setiap hari dan tidak jarang menangis. Orang-orang disekitarnya, pekerjaan dan kegiatan yang tadinya memberikan rasa bahagia baginya kemudian menjadi tidak berarti apa-apa. Gejala depresi dapat diderita dari usia beragam, pada anak-anak depresi dapat berupa penyakit fisik seperti sakit perut, sakit kepala termasuk mudah marah, murung dan perubahan pola makan. Mereka akan merasa tidak antusias terhadap sekolah, dan aktivitas lain.

Apa perbedaan antara depresi dengan perasaan tidak bahagia? Terdapat perbedaannya, dan ketika seseorang telah mengalami kedua hal itu, makan akan tahu perbedaannya. Ketika tidak bahagia, bahkan ketika anda mengalami yang paling parah sekalipun, anda masih dapat mencari rasa nyaman dan membiarkan rasa itu meredakan rasa sakit. Anda dapat mencari dan mendapatkan simpati dan perhatian dari orang lain. Namun dalam depresi, tidak ada hal itu, baik simpati dan perhatian dari orang lain. Orang lain mungkin berada di sisi anda dan menawarkan seluruh kasih, simpati dan perhatian yang diinginkan, namun tak ada yang dapat memecahkan tembok yang memisahkan anda dari mereka, saat didalam tembok itu anda tidak hanya masih menolak pertolongan tersebut namun sekaligus menghukum diri anda dengan perkataan dan perbuatan. Depresi adalah penjara dimana anda adalah narapidana yang menderita sekaligus sipir yang kejam. (Rowe, 2003)

\section{Depresi dan Bunuh Diri}

Depresi merupakan faktor utama bunuh diri. Keputus asaan yang berlarut dan tanpa pertolongan seiring dengan depresi dapat menjadikan bunuh diri sebagai satu-satunya jalan keluar dari rasa sakit yang ada. jika terdapat orangorang disekitar anda yang mengalami depresi, tindak secara serius jika mereka menyinggung masalah bunuh diri dan belajar untuk memahami tanda-tandanya.

Beberapa tanda bunuh diri meliputi:

1. Berbicara mengenai bunuh diri atau menyakiti diri sendiri.

2. Mengekspresikan perasaan yang kuat mengenai hopelessness atau rasa terperangkap.

3. Kelakuan yang janggal mengenai kematian.

4. Bertingkah laku sembrono seakan mereka menginginkan untuk mati.

5. Menelpon atau mengunjungi orangorang untuk mengucapkan perpisahan

6. Menyelesaikan urusan yang belum tuntas

7. Mengatakan hal-hal seperti "semua orang akan lebih baik tanpa saya" atau " saya ingin keluar" atau "Saya ingin semua ini selesai"

8. Perubahan mendadak dari tingkah yang sangat depresi menjadi tenang dan bahagia.

Kekerasan Pada Anak

Penganiayaan anak atau penyalahgunaan anak adalah kekerasan secara fisik, seksual atau psikologis atau kelalaian pada seorang anak terutama oleh orang tua atau pihak asuh lainnya . Hal ini termasuk tindakan lain atau gagal bertindak oleh orang tua atau pihak asuh lainnya yang mengakibatkan potensi bahaya untuk anak yang dapat terjadi di rumah anak tersebut atau di dalam organisasi sekolah atau komunitas dimana anak tersebut berinteraksi. 
Terdapat beberapa jenis kekerasan pada anak yaitu kekerasan fisik, kekerasan psikologis, menelantarkan anak dan kekerasan seksual. Kekerasan fisik dikategorikan dengan luka fisik (sebagai contoh, memar dan retak tulang) yang disebabkan oleh tonjokan, pukulan, tendangan, pembakaran, atau apapun yang menyakiti anak. Juga termasuk luka yang disebabkan bukan dengan kecelakaan, orang tua dan orang yang mengasuh tidak memiliki intensi untuk menyakiti si anak, luka yang disebab dapat merupakan suatu bentuk dari tindakan mendisiplinkan atau hukuman fisik yang tidak pantas dilakukan pada anak. (Depanfilis \& Salus, 1994)

Anak yang memiliki sejarah diabaikan orangtua atau mendapat kekerasan fisik memiliki resiko dalam perkembangan psikologis atau sebagaiman yang disebut dengan disorganized attachment. Hal ini dapat menimbulkan berbagai macam masalah mental termasuk gejala disosiatif seperti axiety (kecemasan berlebih), depresi, bunuh diri, gejala acting out (mekanisme pengendalian/pertahanan diri contoh: mabuk,judi, ketagihan sex dsb.). Ketika anak-anak tersebut kemudian menjadi orangtua, terutama jika mereka mengalami gangguan pasca trauma (PTSD), mereka memungkinkan untuk menemui kesulitan menghadapi anak mereka yang mana akan berpengaruh pada perkembangan mental sosial anak.

The Machinist

Film The Machinist (2004) merupakan sebuah film thriller yang menceritakan tentang seorang pekerja pabrik mesin yakni Trevor Reznik (Christian Bale) yang menderita insomnia akut, sangat akut hingga mempengaruhi berat badan dan kesehatan mentalnya. Ketika Trevor secara tidak sengaja mengakibatkan teman kerjanya meng- alami kecelakaan pabrik, kondisi Trevor menjadi semakin parah, ia mengalami paranoid dan mulai menyalahkan seorang figur bernama Ivan. Hampir separuh film penonton dibuat percaya bahwa Ivan lah dalang dari seluruh malapetaka yang dialami Trevor, namun ternyata Ivan hanyalah sosok semu belaka yang diciptakan sendiri oleh Trevor karena rasa bersalah masa lalunya yang pernah melakukan tabrak lari pada seorang anak kecil. Hal inilah yang memicu mengalami depresi dan insomnia dan berujung pada halusinasi. Film ini dikemas dengan nuansa gelap, sadis dan tegang. Sepanjang film sebenarnya penonton tanpa sadar telah diberi petunjuk satu per-satu yang mengarah pada akhir cerita, namun barulah ketika seluruh gambaran dapat disatukan maka semuanya menjadi masuk akal.

\section{Edmond Was a Donkey}

Animasi pendek yang ditulis oleh Frank Dion seorang penulis asal perancis dan dirilis pada tahun 2004. Menceritakan tentang seorang pekerja kantoran bernama Edmond. Tidak seperti kebanyakan orang, ia memiliki tubuh kecil dan sangat pendiam. Edmond menjalani hari dengan rutinitas yang sama hingga pada saat ketika teman kerjanya memakaikan topi dengan dua telinga seperti keledai, ia tiba-tiba menemukan jati dirinya. Edmond sangat menikmati identitas barunya sebagai keledai, namun obsesinya menjadi berlebihan hingga pada akhirnya Edmond dimasukan ke rumah sakit jiwa. Setelah dibebaskan dari rumah sakit, Edmond yang diharapkan dapat kembali normal malah lebih memilih untuk tetap merasakan perasaan damai sebagai seekor keledai. Edmond pun kemudian bunuh diri di tempat kerjanya. Namun disinipun digambarkan bahwa ia menikmati kematiannya karena pada akhirnya ia dapat dengan tenang menjadi keledai sesuai keinginannya selama ini. 
Edmond digambarkan memiliki kehidupan monoton dan membosankan, hal ini juga tergambarkan dengan tone film yang abu-abu dan pudar, sampai kulit karakterpun berwarna pucat sehingga benar-benar memberikan kesan yang kelam dan kaku. Film ini menyajikan cerita yang berbeda, aneh dan penuh dengan kejanggalan dan tanda tanya. Penonton dibuat merasa tidak nyaman dengan visual karakter, suasana maupun konflik didalamnya. Pada akhir cerita pun tidak diberi penjelasan dari maksud keledai pada cerita ini, disinilah penonton dipaksa untuk membuat kesimpulan sendiri dengan membuat interpretasi sendiri terhadap makna cerita tersebut.

\section{A Beautiful Mind}

Film ini merupakan adaptasi dari kisah nyata seorang profesor. John Nash, seorang ahli matematika brilian ternyata menderita schizophernia dan hal ini memutar balikan dunianya dan meragukan apa yang ia percayai selama ini. Masamasa depresi muncul dan digambarkan terlebih pada saat setelah Nash keluar dari rumah sakit setelah menjalani perawatan yang menyiksa. Nash kehilangan kemampuannya untuk berpikir cepat menyelesaikan soal-soal matematika yang dulu terlihat sangat mudah baginya dikarenakan ia mengkonsumsi obat untuk penyakit mentalnya. Tidak hanya pada Nash, depresi juga terlihat pada istrinya yang seperti tejebak pada keadaan. Namun pada akhirnya Nash dan Istrinya berhasil melewati masa-masa sulit tersebut. Pada film ini, penonton dibuat benar-benar percaya dan sepenuhnya "berpihak" pada Nash untuk sesaat, dan disinilah letak keunikan film ini. Adegan pada film diatur sedemikian rupa sehingga tanpa penjelasan yang gamblang, seiring berjalannya alur, penonton semakin mengerti keadaan yang tengah terjadi.

\section{ReMoved}

Merupakan sebuah film pendek yang menceritakan seorang gadis berumur 10 tahun tentang perjalanannya dari pintu ke pintu rumah asuh setelah dirinya dipindahkan dari rumahnya dan dipisahkan dengan adik laki-lakinya. Zoe dipisahkan dari kedua orang tuanya berdasarkan hukum negara amerika yang akan mengambil alih hak asuh anak jika orangtua dianggap tidak pantas/tidak layak/tidak mampu memenuhi standard untuk mengasuh anaknya. Zoe berasal dari keluarga yang berantakan, ia dan adik laki-lakinya tinggal bersama ibu kandung dan ayah tirinya. Namun sang ayah kerap mabuk dan memukul ibunya dan Zoe hingga babak belur. Di dalam film, digambarkan bagaimana cerita seorang anak yang mengalami tindak kekerasan rumah tangga dan harus berhadapan dengan sistem asuh di Amerika. Perasaan depresi Zoe juga terasa karena sepanjang film terdapat narasi dengan suara Zoe, menceritakan perasaannya dari kejadian demi kejadian. Film ini memiliki alur maju yang linear namun terdapat permainan perasaan empati pada film ini yang membuat penonton ikut terbawa kedalam cerita.

\section{Karakter Depresi}

Seorang penderita depresi pada umumnya tidak memiliki ciri fisik tertentu. Seseorang tidak dapat dinilai langsung sebagai penderita depresi hanya dengan melihat saja. Namun begitu, salah satu gejala pada orang depresi adalah kurang tidur akibat ketidaknyamanan pada dirinya sendiri (overthinking), dan beberapa ciri fisik yang paling menonjol pada orang yang kurang tidur adalah terdapat kantung mata, lesu, berantakan dan pucat. Penulis pun menemukan kesamaan fitur tersebut pada beberapa film yang juga bertemakan depresi. 


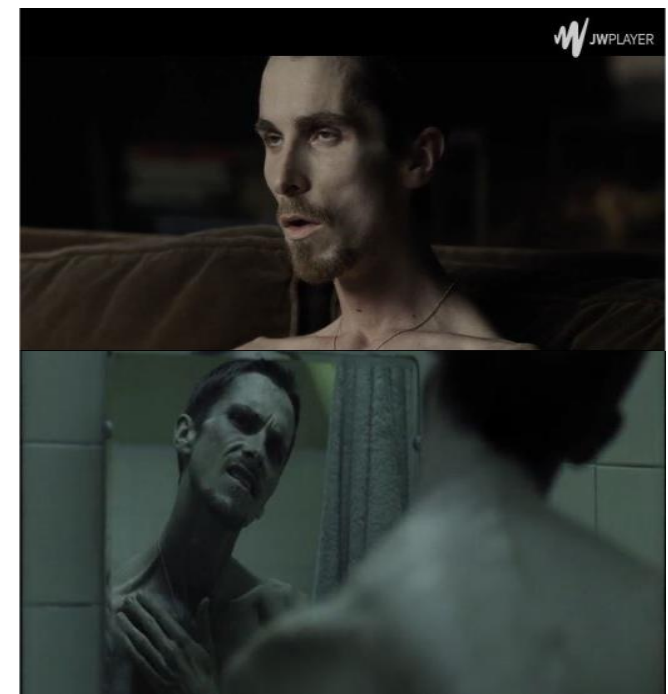

Gambar 2.2

Trevor Reznik Pada film The Machinist

Pada film the machinist, Trevor digambarkan mengalami insomnia dan mempengaruhi berat badanya. Trevor digambarkan sangat kurus hingga dapat dianggap menyeramkan dan tidak enak dipandang. Selain itu, matanya pun merah dan memiliki kantung mata karena kekurangan tidur.

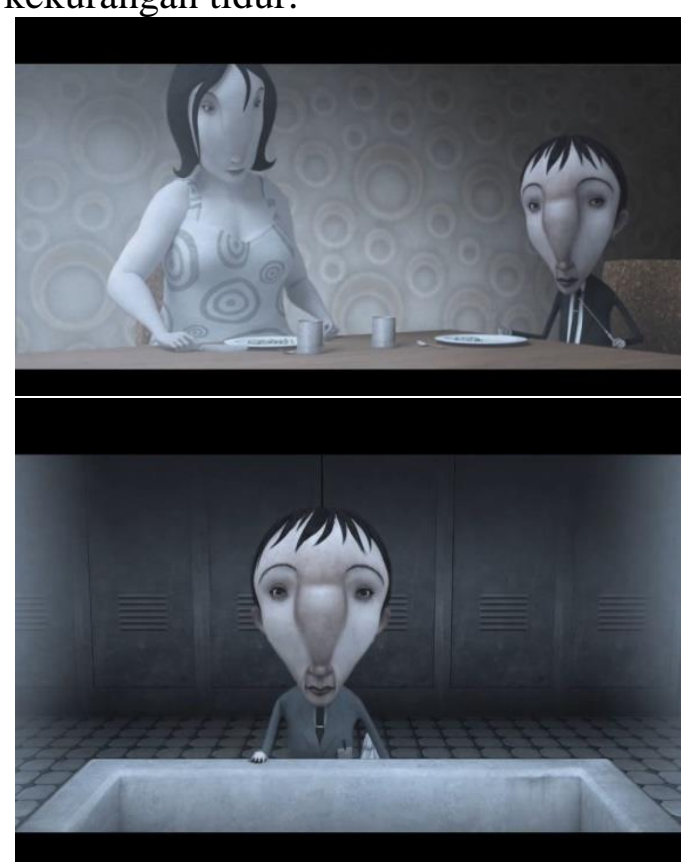

Gambar 2.3

Edmond pada film Edmond Was a Donkey

Salah satu contoh lain yang penulis pelajari adalah dari film pendek animasi Edmond was a donkey, Tokoh
Edmond yang diceritakan mengalami depresi hingga bunuh diri, digambarkan dengan bentuk wajah yang unik dan cenderung menyeramkan. Walaupun tidak digambarkan dengan kantung mata, namun proporsi kepala yang abnormal dan jarak kedua mata yang cukup jauh memberikan kesan "alien" pada karakter ini. Selain itu warna kulit karakter juga sangat pucat tidak seperti orang pada umumnya. Kombinasi fitur-fitur tersebut yang menjadikan karakter Edmond mencolok dan berbeda.

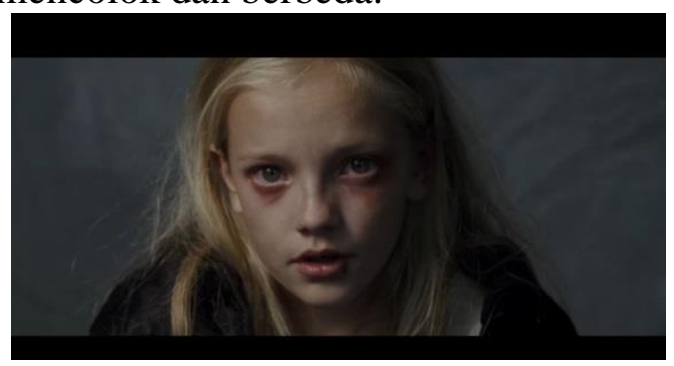

Gambar 2.4

Karakter Zoe pada film pendek ReMoved

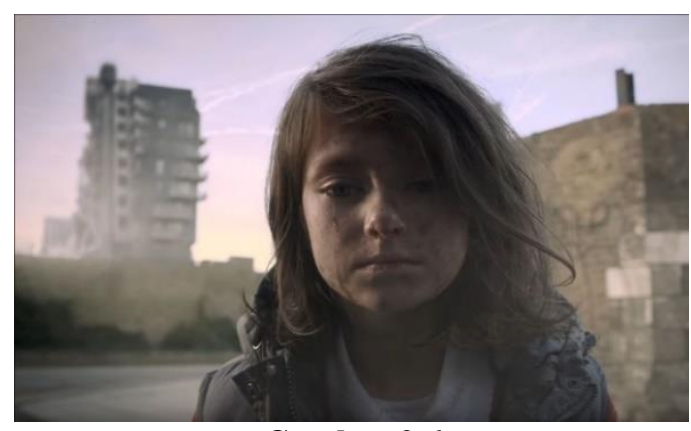

Gambar 2.6

Karakter PSA save the children

Sosok seorang dengan depresi seringkali digambarkan dengan kesan sedikit menyeramkan dan beberapa fitur dibuat lebih ektrim seperti ukuran kepala dan mata yang dibuat lebih besar untuk menonjolkan mata yang sembab, berkantung, dan seram. selain itu rambut kurang diatur juga menambah kesan tidak terawat dan berantakan karena depresi. 


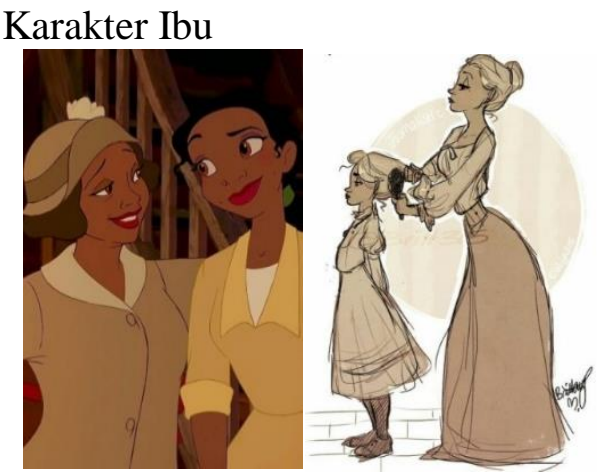

Gambar 2.7 Karakter ibu

Sosok ibu digambarkan penuh kasih sayang dan memiliki hubungan yang erat dengan anaknya, terutama dengan anak perempuan. Namun begitu, ibu juga memiliki karakter yang tegas dan bijaksana. Ibu digambarkan memiliki rambut yang pendek/diikat karena memudahkan untuk bekerja dan mengerjakan pekerjaan rumah. Sosok ibu pada film Tangled digambarkan memiliki mata besar yang membelalak, dagu yang sangat runcing dan tulang pipi yang menonjol, ini karena karakter tersebut juga merupakan karakter antagonis. Namun, disamping antagonis sifat mother Gothel juga digambarkan tangguh, keras dan mandiri.

\section{Studi warna}

Pencahayaan dan warna dapat menonjolkan sebuah adegan pada film melalui berbagai jenis palet warna, color tone, contrast dan hues. Pemilihan warna pada keseluruhan film dapat mempengaruhi mood pada setiap adegan. Tidak mustahil seiring berjalannya cerita pada sebuah film, skema warna pun ikut berubah menyesuaikan dengan kebutuhan $\operatorname{mood}$ cerita.

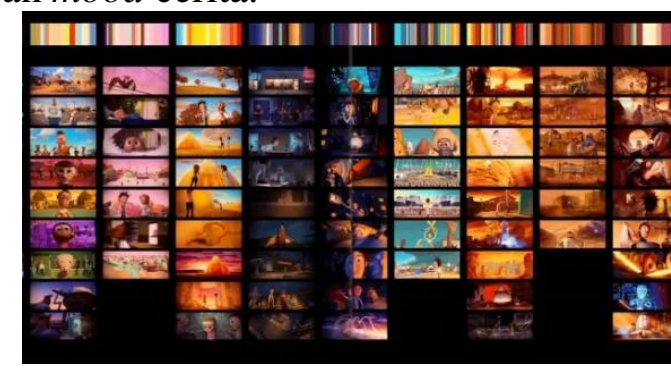

Gambar 2.8 Color script film cloudy with a chance of meatballs
Agar warna yang dipakai dalam animasi memiliki korelasi dan dapat menyampaikan suasana yang tepat, maka penulis melakukan beberapa studi warna pada beberapa karya animasi.

Pada film animasi Princess and the frog dapat terlihat beberapa adegan yang menggunakan warna dengan kontras yang cukup mencolok. Kesan mencolok ini ditimbulkan karena pemilihan warna yang berseberangan pada colorwheel sehingga dapat dikatakan warna tersebut bertentangan. Seperti pada concept art dari adegan parade yang menggunakan warna pink kemerahan ditambah keylight warna biru terang dengan sedikit warna oranye, ketiga warna ini merupakan color harmony triadic pada colorwheel, selain itu dengan saturasi yang tinggi maka semakin terlihat kontrasnya warna tersebut. Suasana yang dihasilkan terkesan meriah, panas dan sedikit menindas, karena pada adegan ini yang mendominasi adalah warna fuschia.

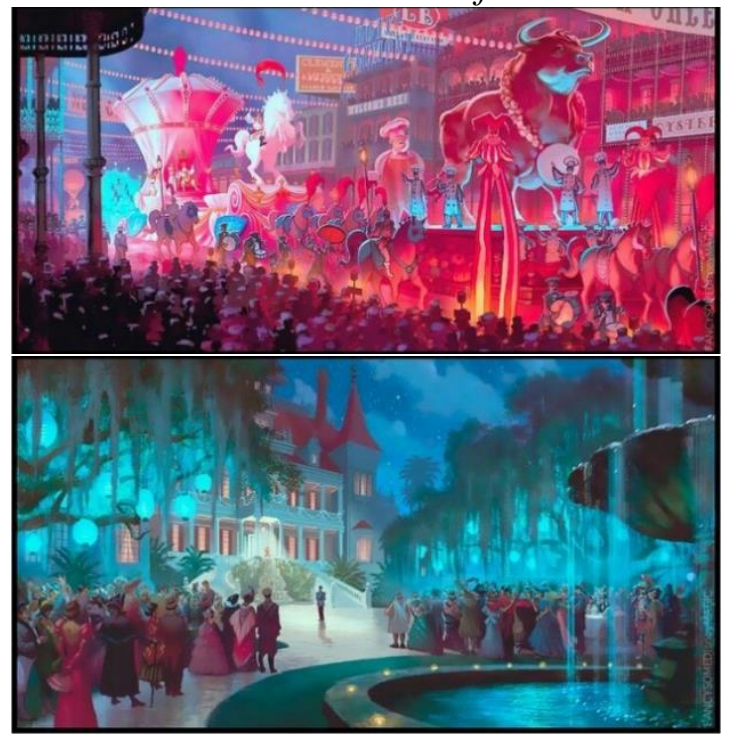

Gambar 2.9

Concept art princess and the frog

Berbeda dengan scene parade, pada scene pesta, walaupun warna yang digunakan sama, hanya dengan mengubah warna dominannya saja sudah dapat membuat perbedaan suasana yang 
sangat besar. Pada adegan pesta, warna yang digunakan masih sama yakni biru, merah muda dan oranye. Hanya saja kali ini didominasi dengan warna biru dengan warna lain sebagai pelengkap. Suasana yang ditimbulkan lebih tenang, dingin, elegan dan lebih enak untuk dilihat.

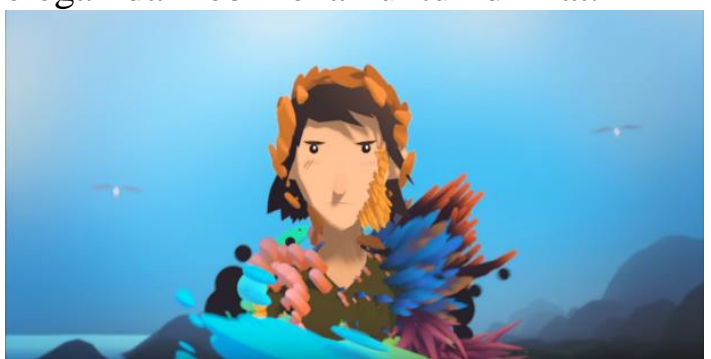

Gambar 2.10

MV panda bear-boys latin

Pada animasi Boys Latin pewarnaan yang digunakan memberikan kesan 2D walaupun animasinya berupa 3D. Hal ini dikenal dengan teknik cell-shading. Bayangan pada objek dibuat solid dan tidak realis sehingga menimbulkan kesan kartun.

\section{Studi Sinematografi}

Penulis melakukan studi sinematografi untuk menentukan penggunaan angle pada kamera yang ingin dipakai dalam animasi. penulis melakukan studi pada animasi PSA Mask dan short film Le Miroir.

Pada animasi Mask, pengambilan gambar sepanjang film selalu mengikuti gerak kepala karakter utama. Walaupun dengan angle yang terbatas, namun cerita dapat disampaikan dengan baik dengan memanfaatkan latar tempat dan ekspresi karakter utama.

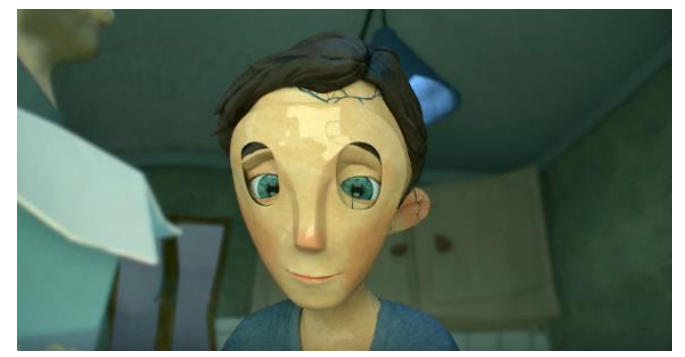

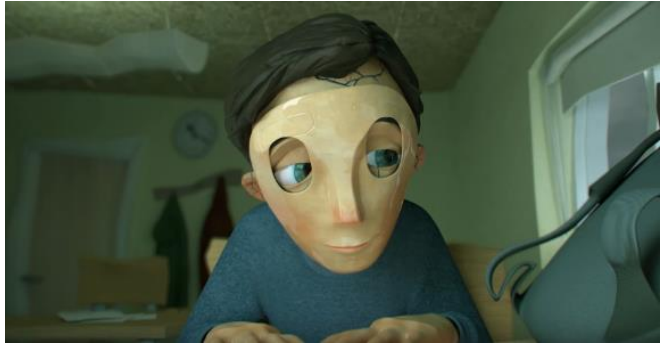

Gambar 2.11

Camera angle animasi Mask

Pada Le Miroir, sepanjang film menggunakan angle dari POV (Point of View) sehingga gerakan kamera menyerupai pengelihatan karakter pada film tersebut. Hal ini menambahkan kesan nyata bahwa seakan-akan penontonlah yang menjadi karakter pada film tersebut.

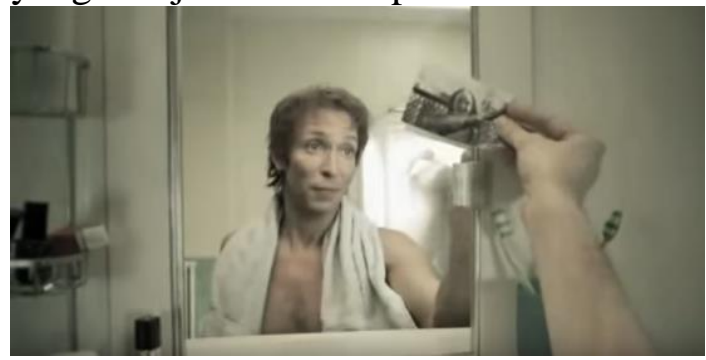

Gambar 2.12

First person point of view pada Le Miroir

\section{METODE PENELITIAN}

Selama proses penelitian, penulis menerapkan metode perancangan yakni metodologi desain sebagai berikut.

\section{Metodologi Desain}

Dalam proses mendesain terdapat 7 tahap yakni define, research, ideate, prototype, select, implement dan learn. Keempat tahap pertama merupakan tahap-tahap yang dilakukan pada proses preproduksi. Berikut penjelasan lebih lanjut mengenai tahapan tersebut:

\section{Define}

Merupakan tahapan pertama dalam proses mendesain dan hampir selalu melibatkan membuat atau menerima design brief (desain awal). Ide awal memiliki tujuan spesifik yang harus 
dipenuhi oleh desain, namun juga memiliki kemungkinan untuk ditulis dalam istilah dengan interpretasi beragam. Ide awal dapat berupa sesuatu yang sangat sederhana seperti contohnya "Kami membutuhkan brosur yang dapat membuat kami terlihat keren dan bergaya" seorang desainer harus dapat mengartikan ide awal tersebut dan menetapkan apa yang dimaksud dengan "keren" dan "bergaya". Tahap ini juga dapat mempertanyakan kembali kebenaran elemen pada ide awal.

\section{Research}

Tahap dimana mengumpulkan latar belakang informasi. Ketika ide awal sudah ditetapkan dan disetujui, desainer mulai untuk mencari informasi yang dapat digunakan dalam proses kreatif pada tahap ideation. Tahap riset ini dapat berupa kuantitatif, dengan fakta statistik mengenai ukuran dan komposisi dari kelompok pengguna atau kualitatif, dengan informasi mengenai apa yang dibeli atau dikonsumsi oleh kelompok pengguna dan bagaimana gaya hidup mereka. Hal ini termasuk berbagai faktor seperti edukasi, karir, tujuan liburan, selera musik, tujuan hidup dan lain lain. Pada tahap ini juga meliputi riset primer dan sekunder. Pada riset primer, sumber utama riset adalah feedback yang terbentuk pada fase pembelajaran dari proyek sebelumnya yang dilakukan dengan klien yang serupa/sama riset sekunder, merupakan informasi yang didapat dari sumber sekunder seperti laporan riset pasar. Riset ini menyediakan laporan demografis dan performa dari segmen pasar dan menyediakan gambaran yang jelas dari struktur pasar.

\section{Ideate}

Tahap ini dimana menciptakan solusi yang berpotensi. Pada masa ideation, desainer mengacu pada penelitan yang dikumpulkan dan kendala yang ada pada saat tahap ide awal / define. Informasi tersebut digunakan untuk membuat ide yang menjadi solusi bagi ide awal (design brief). Desainer menggunakan metode berbeda pada tahap ini. Metode ini meliputi brainstorming, sketsa ide, mengadaptasi desain yang sudah ada sebelumnya, mengambil pendekatan analitik yang fokus pada produk, servis atau perusahaan atau pendekatan dasar yang fokus pada pengguna. Setiap metode melibatkan berbagai macam tingkat kreatifitas dan memilih metode mana yang akan dipakai tergantung dari faktor seperti seberapa besar dana yang ada dan se-original apa desain yang harus dibuat. Pada tahap ini, tim desain juga mungkin harus memilih untuk memanfaatkan satu dari sekian banyak gerakan atau pila pikir seni dan desain. Pada tahap ini juga akan memberikan pencerahan apakah terdapat kesalah pahaman atau kekurangan pada tahap define dan apakah penilitian yang dilakukan sudah cukup. Feedback dapat diminta pada tahap ini untuk mengklarifikasi keraguan dan mengarahkan aspek yang salah diartikan pada proses define.

\section{Prototype}

Pada tahap ideate, telah dihasilkan variasi beberapa solusi yang potensial. Dibutuhkan untuk mengembangkan lebih jauh solusi yang paling menjanjikan. Ini akan memungkinkan aspek-aspek untuk di uji dan menyediakan dasar yang lebih baik sebagai pembanding pada tahap seleksi. Dalam hal ini, sebuah purwa-rupa dapat dibuat. Sebuah purwa-rupa dapat dipakai untuk uji coba kemungkinan teknis dari desain ide untuk melihat apakah ide tersebut bekerja dengan baik sebagai objek fisik. Kemasan baru atau ide presentasi pada umumnya membutuhkan pengembangan purwa-rupa. Sebuah purwa-rupa dapat juga menguji aspek 
visual dari sebuah desain dengan mempresentasikan itu sebagaimana akan di produksi. sebuah purwa-rupa memberikan tim desain dan klien sebuah gambaran mengenai konsep desain, untuk mendapatkan ide mengenai bentuk fisik dan kualitas taktilnya. Sebagaimana purwa-rupa menargetkan untuk menguji aspek tertentu pada solusi desain, maka harus dibuat sedemikian rupa sehingga aspek tersebut dapat terwujud dan dapat secara efektif dievaluasi. Untuk menyampaikan bagaimana sebuah hasil akhir akan dibuat, sebuah purwa-rupa tidak harus dibuat dengan material asli. Sebagai contoh, model arsitektur sering dibuat menggunakan karton putih guna untuk memberikan visual 3 dimensi sebuah bangunan. Namun bagaimanapun, jika ditetapkan maka akan mungkin elemen bersangkutan dipresentasikan melalui purwa-rupa.

\section{Select}

Pada tahap select atau pemilihan adalah poin dimana satu dari solusi desain dipilih dan dikembangkan. Tipikalnya, desain yang terpilih merupakan desain yang paling mendekati dengan brief awal, atau mengandung beberapa bagian dari brief tersebut. Karena memang tidak mungkin untuk memenuhi semua yang dituntut dari sebuah brief dengan hanya satu desain. Sebagai contoh, segmen pasar mempengaruhi marketing yang berbeda dan solusi desain yang berbeda pula.

Faktor lain, seperti biaya dan waktu, juga menjadi salah satu pertimbangan pada tahap seleksi, namun dapat berubah pada proses pengembangan (developing). Anggaran yang ada mungkin saja tidak dapat memenuhi anggaran yang dibutuhkan untuk solusi yang dipilih dengan begitu mungkin alternatif lain yang dapat dipilih. Namun bagaimanapun, anggaran dan tenggat waktu seharusnya sudah diidentifikasi pada saat tahap definition dan harus dipertimbangkan sepanjang proses.

\section{Implement}

Selama tahap ini, desainer memberikan hasil desain mereka denan spesifikasi format kepada orang yang akan bertanggung jawab dalam pembuatan produk final. Pada tahap ini merupakan kesempatan yang baik untuk mengkonfirmasik spesifikasi produksi seperti kuantitas cetak dan seperti apa harapan untuk hasil akhirnya nanti.

Tim desain biasanya mendampingi manajemen proyek selama tahap ini untuk memastikan hasil akhir sama dengan ekspektasi juga menjaga agar proyek tetap pada anggaran dan tepat waktu. Proofing atau pembuktian mungkin diperlukan pada tahap implementasi jika melibatkan percetakan. Untuk website dan media electronik lain, pembuktian berarti mencoba secara fungsi dan juga visual. Tahap ini berakhir dengan pengiriman final kepada klien berupa hasil kerja yang sudah selesai.

\section{Learn}

Tahap final pada proses ini melibatkan pembelajaran dari apa yang sudah dikerjakan sepanjang proses desain. Ini merupakan tahap umpan balik dari apa yang dicari oleh pihak klien dan agensi desain. Apa yang berhasil dan apakah ada yang perlu diperbaiki.

Mengikuti dari implementasi, klien mungkin mulai untuk menerima atau memberikan umpan balik mengenaik bagaimana produk diterima oleh target pasar dan bagaimana keuntungan dari efek target audience. Dari sinilah perusahaan desain dapat menemukan bagaimana pasar merespon terhadap desain mereka.

Umpan balik dari proses ini dapat menjadi kesempatan pembelajaran untuk proyek selanjutnya. Hal ini membentuk 
sebuah sumber informasi untuk tahap define dan research. Permasalahan yang ada pada desain mungkin disebabkan oleh kekurangan brief atau kurangnnya pemahaman pada poin kunci. Pada proses umpan alik, desainer dan klien membangun pemahaman dari waktu ke waktu. Hal ini memberikan penunjang solusi yang optimal dimasa depan (Ambrose dan Harris,2015:10)

\section{Data Primer}

Pengumpulan data primer dilakukan dengan wawancara, yaitu pengumpulan data dengan mengajukan pertanyaan langsung kepada subjek yang bersangkutan terkait dengan tema tertentu, dan jawaban-jawaban pihak yang bersangkutan dicatat atau direkam untuk kemudian ditinjau ulang dan diringkas. Narasumber yang dimaksud adalah:

1. Lembaga Penelitian Psikologi

2. Narasumber dengan latar belakang psikologi

3. Subyek Penderita Depresi

4. Subyek dengan pengalaman terkait Depresi (kerabat atau teman)

5. Penelitian terhadap subyek penderita Depresi baik pernah mengalami atau sedang mengalami.

\section{Data Sekunder}

1. Pengumpulan data literatur dan internet

2. Metode Kepustakaan; adalah metode dengan cara mencari informasi yang dibutuhkan melalui media cetak. Sumber dapat berupa buku, majalah, surat kabar, jurnal, penelitian sebelumnya dll.

\section{Metode Analisa Data}

Analisa data yang dilakukan dalam perancangan ini adalah dengan menganalisa data wawancara, data literatur dan internet.

\section{HASIL DAN PEMBAHASAN}

\section{Penulisan Judul "Agony"}

Untuk desain judul, penulis menggunakan font "Edge" yang memiliki goresan-goresan seperti tulisan tangan dengan ujung-ujungnya yang berkesan kasar. Tulisan AG dan NY berwarna abuabu tua dan huruf $\mathrm{O}$ diganti dengan bentuk gulali berwarna merah muda yang merupakan makanan kesukaan pemeran utama pada film ini. Selain itu pada huruf-huruf judul juga diberi sedikit tekstur kasar yang mengesankan huruf yang rusak dan tidak mulus namun masih tetap bisa dibaca dengan baik.

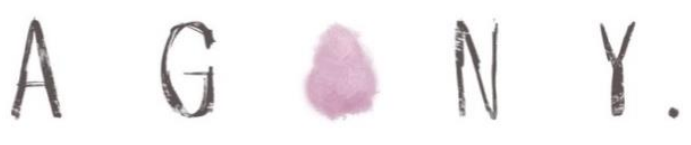

Gambar 4.1 Judul "Agony”

\section{Siene Kecil}

Merupakan seorang anak berumur 7 tahun yang pada dasarnya memiliki kepribadian yang periang dan lucu. Siene kecil memiliki hubungan yang dekat dengan ibunya. Namun Siene kerap kali menerima perlakuan kasar dari orangorang disekitarnya termasuk ayahnya sendiri. Perlakuan kasar ini sering ia alami ketika ia melakukan suatu kesalahan. Penulis menggambarkan Siene kecil serupa dengan sosok Siene yang dewasa untuk tetap menjaga relevansi karakter. Namun begitu, Siene digambarkan lebih terawat dan tetap dijaga kesan "lugu" nya. Karena masih pada tahap anak kecil, Siene kecil memiliki kepala yang lebih besar dari proporsi tubuhnya. Menurut ilmu fisiologi jarak mata yang berjauhan menunjukan orang yang memiliki pandangan luas dan kreatif. Karakter Siene pada intinya memang merupakan seseorang yang pada mulanya memiliki kecenderungan sifat demikian 

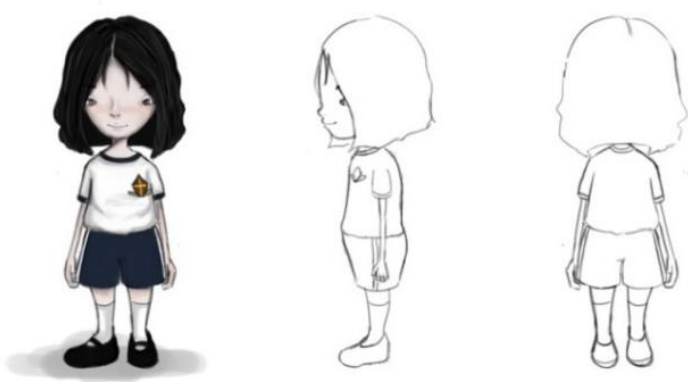

Gambar 4.2 Konsep Siene Kecil

\section{Siene (remaja)}

Siene remaja berumur 16 tahun yang sepanjang hidupnya kerap kali menerima berbagai kekerasan fisik baik dari lingkungannya maupun ayahnya. Hingga pada saat ia tumbuh dewasa barulah hal tersebut mulai berhenti. Namun Siene terlanjur mengalami depresi yang mengakibatkannya sulit tidur dan kurang merawat diri. Siene remaja digambarkan memiliki rambut berantakan, lengan yang kurus dan kedua mata yang memiliki kantung hitam dibawahnya akibat selalu sulit tidur. Siene memiliki letak mata yang dalam, menunjukan kepribadianya yang tertutup dan suka menyendiri.
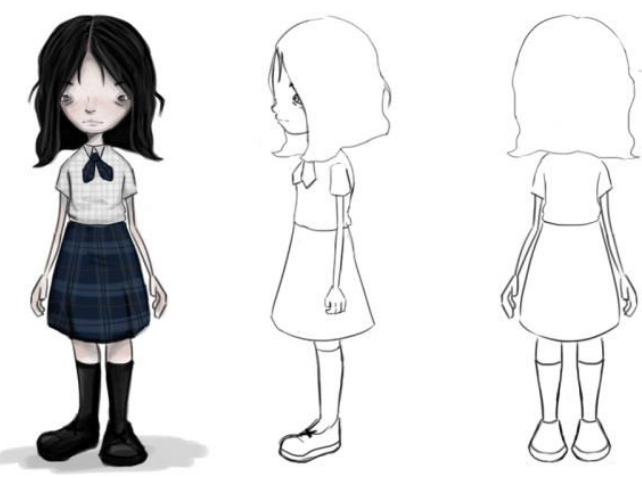

Gambar 4.3 Konsep Siene Remaja

Ibu

Sosok Ibu memiliki hubungan yang dekat dengan Siene, walaupun begitu, ia selalu memendam rasa bersalah karena gagal menjadi ibu yang baik bagi Siene. Ia kerap bertengkar dengan suaminya yang memang ringan tangan dan tempramental. Ibu digambarkan bertubuh kurus dan juga memiliki kantung mata yang memberi kesan letih dan menggambarkan perjuangannya sebagai seorang ibu. Ibu juga memakai baju rumah dan dengan celemek karena kegemarannya yang suka memasak untuk Siene.

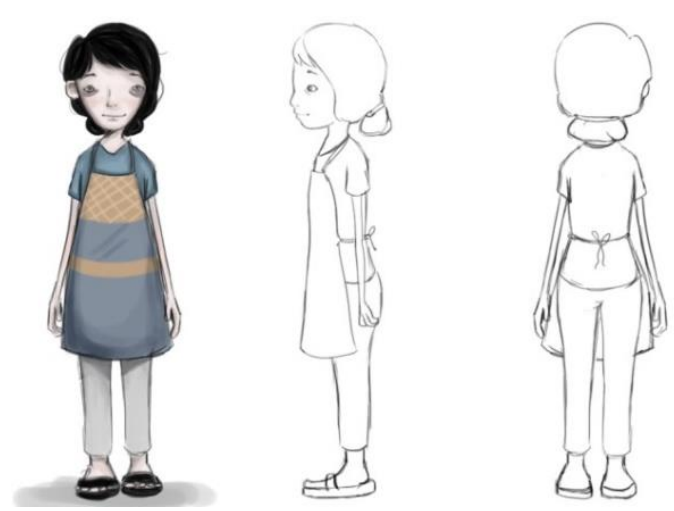

Gambar 4.4 Konsep Ibu

\section{Dapur Rumah}

Dapur rumah yang dipakai pada adegan awal saat Siene masih kecil, disinilah Siene seringkali terkena pukul oleh ayahnya. Konsep dapur dibuat sedemikian rupa hingga menggambarkan kesan yang sederhana, selain itu dapur juga dibuat berukuran kecil dan sempit.

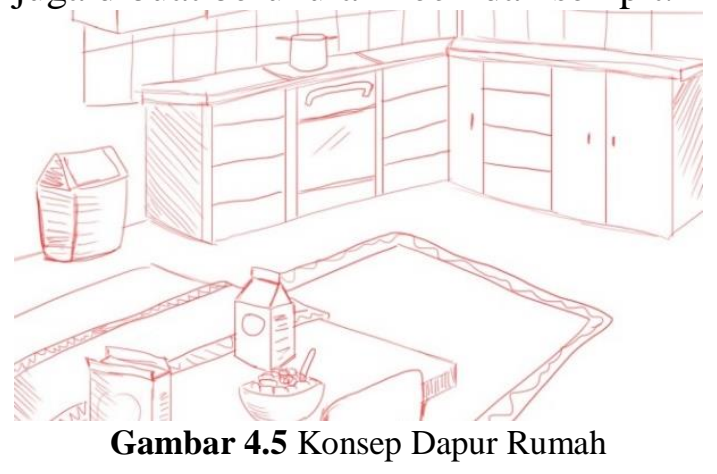

\section{Ruang Kelas}

Konsep ruang kelas dibuat seperti pada ruang kelas umumnya, dengan meja berjajar dan terdapat jendela di sepanjang tembok ruang kelas untuk memberikan pencahayaan tambahan. 


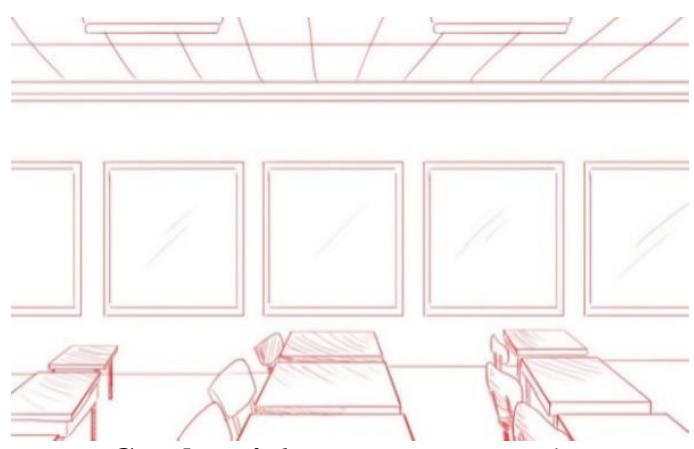

Gambar 4.6 Konsep Ruang Kelas

\section{Jalanan}

Latar tempat pada film animasi ini mengacu pada latar daerah pinggiran kota yang sudah cukup maju. Jalannya pun dikelilingin oleh toko-toko dan beberapa bangunan ruko, selain itu di sepanjang jalan terdapat pepohonan rindang dan trotoar tempat bagi pejalan kaki untuk berlalu lalang.

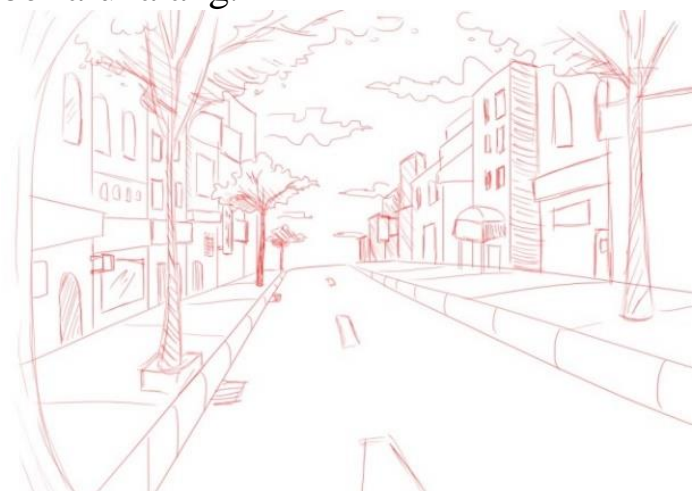

Gambar 4.7 Konsep Jalanan

\section{Premis Cerita}

Siene tumbuh dalam kekerasan, dan satu-satunya orang yang melindunginya adalah sang Ibu yang telah lama pergi. Hingga pada suatu hari ia bertemu anak kecil yang dapat mempertemukannya kembali dengan Ibunya.

\section{Penetapan Judul Animasi}

Untuk judul film, pada awalnya penulis memilih "Saiwaz" yang berasal dari bahasa eropa kuno yang secara harafiah berarti "berasal atau kepunyaan laut" sebagai tempat dimana roh-roh berasal. Namun oleh inggris kuno juga dapat diartikan sebagai “jiwa, orang, raga dan manusia". Kemudian penulis mengambil judul "Agony" yang berasal dari bahasa Perancis kuno yang berarti perasaan mental atau fisik yang mengalami penderitaan ekstrim. Juga dapat diartikan sebagai tahapan akhir dari kematian yang sulit dan menyakitkan.

\section{Story Style}

Cerita pada animasi ini dibuat sengaja dengan plot twist di bagian akhir. Penonton dibuat percaya pada suatu pandangan dan kemudian fakta yang ada diputar balikan sehingga menimbulkan cerita yang lebih menarik. Walaupun alur sebagain besar linear, namun pada bagian akhir terdapat flashback yang sekaligus berfungsi sebagai pemecahan konflik pada cerita. Selain itu, terdapat unsur semiotik pada cerita yang memaksa penonton untuk lebih aktif dalam membuat presepsi untuk mengerti pesan yang ingin disampaikan oleh animasi ini.

\section{Visual Style}

Menonjolkan fitur karakter yang yang unik dan tidak biasa dengan bentuk yang masih menyerupai manusia namun telah mengalami exageration untuk menimbulkan kesan aneh, sedikit seram dan tidak nyaman. Keseluruhan look akan disajikan dengan hasil render semi realistis dengan pencahayaan cukup kontras yang menghasilkan kesan lebih dramatis. Selain itu ditambah lighting editing sedemikian rupa yang memberikan kesan suram, dengan tetap mempertahankan kualitas warna dan pencahayaan. Terdapat perbedaan pada style environment, tidak seperti objek dan karakter pada film, environment background dibuat dengan style digital painting dengan memainkan depth of field yang cukup jauh sehingga memiliki kesan ruang yang lebih unik.

Selain visual pada karakter dan environment, pada animasi ini juga lebih memakai sudut pandang kamera dari 
point of view karakter dan objek. Perbedaan terbesar terdapat pada saat Siene kecil dan pada saat Siene sudah besar. Pada saat Siene kecil, kamera akan terus menyorot wajah Siene kemanapun kepalanya bergerak sedangkan ketika Siene sudah remaja, angle kamera berubah menjadi P.O.V Siene namun tetap pada beberapa adegan menggunakan P.O.V benda lain untuk mendapatkan gambaran secara keseluruhan.

\section{Motion Style}

Animasi pendek ini memiliki motion style beragam. Karena pada beberapa adegan tertentu dibutuhkan intensitas ketegangan yang mendukung sehingga membangun mood penonton dengan baik. Namun sebagain besar pergerakan kameranya terbilang lamban mengikuti arah gerak karakter karena kebanyakan angle kamera diambil dari point of view karakter tersebut.

\section{Karakter dan Environment}

Terdapat 3 karakter utama pada animasi pendek "Agony". Karakter tersebut memiliki kepribadian dan fitur yang serupa karena kemiripan perilaku. Selain itu dua diantaranya pun mengidap depresi sehingga terdapat fitur yang sama-sama ditonjolkan.

1. Siene kecil

Siene yang masih kecil masih memiliki kepribadian lugu, periang dan polos sehingga wajahnya belum memiliki kesan depresi atau menyeramkan. Siene kecil memakai baju seragam olah raga sekolahnya karena Siene merupakan murid SD.

2. Siene Remaja

Siene yang sudah remaja memiliki mata yang lebih sembab dan dengan kantung mata hitam yang cukup mencolok. Hal ini karena Siene kerap kali menerima kekerasan fisik ditambah kematian sang ibu yang mengakibatkannya menderita depresi yang berlarut-larut. Rambut Siene pun digambarkan lebih panjang dan tidak terawat dan menutupi wajahnya, memberikan kesan berantakan,seram dan juga tertutup.

3. Ibu

Sosok ibu digambarakan juga memiliki kantung mata, karena sang ibu pun menderita depresi karena merasa gagal sebagai orang tua. Juga kerap menerima perlakuan tidak baik dari sang suami. Ibu digambarkan memiliki karakter yang lemah lembut terhadap Siene namun berani melindungi Siene dari sang suami. Ibu juga memakai celemek yang mengesankan sosok ibu rumah tangga yang gemar memasak untuk anaknya.

Sedangkan untuk perancangan environment yang akan digunakan adalah sebagai berikut:

1. Dapur rumah.

Dapur sederhana dengan ukuran yang tidak terlalu besar. Terdapat berbagai perabotan dapur yang berantakan. Tempat dimana Siene kecil sering menggambar sembari meminum susunya setiap pagi untuk sarapan.

2. Sisi Jalan raya.

Suasana pinggir kota dengan jalan bagi pejalan kaki dikedua sisi jalan. Banyak terdapat toko-toko kelontong, toko roti dan berbagai ruko sepanjang jalan. Beberapa pohon di tempatkan sepanjang jalan namun tidak terlalu rindang. Jalan raya sendiri memiliki 2 jalur mobil namun tidak terlalu lebar.

3. Dalam kelas

Ruang kelas cukup besar dengan jendela di sepanjang tembok kelas sehingga cahaya yang masuk cukup terang. ruang kelas dibuat sederhana dan polos untuk memberi kesan monoton dan membosankan. Meja dan kursi juga tertata dengan rapih. 
4. Pinggir lapangan sekolah

Terdapat pepohonan yang rindang dipinggir lapangan, dibawah pohon ditempatkan kursi semen untuk murid beristirahat atau sekadar duduk. Merupakan tempat favorit Siene untuk makan siang karena ia selalu makan siang sendirian.

5. Taman kota

Tempat dimana Siene pada akhirnya bertemu dengan ibunya. Taman kota memiliki banyak bunga dan dengan kesan rimbun yang teduh. Terdapat lampu-lampu taman dan kursi taman di pinggir jalan taman kota.

6. Kantor polisi

Kantor polisi dibuat dengan suasana sepi karena berada di kota kecil yang tidak banyak peristiwa. Hanya terdapat meja resepsionis dan bangku plastik untuk menunggu.

\section{Konsep Desain}

Penulis membuat beberapa perancangan visual akhir yang kira-kira ingin dicapai dalam pembuatan animasi.

Ibu digambarkan sebagai sosok yang sangat menyayangi Siene sebagai anak satu-satunya. Itulah sebabnya walaupun berhati lembut, ibu tetap memiliki watak yang keras untuk melindungi Siene. Ibu juga orang yang tegas dan pekerja keras.

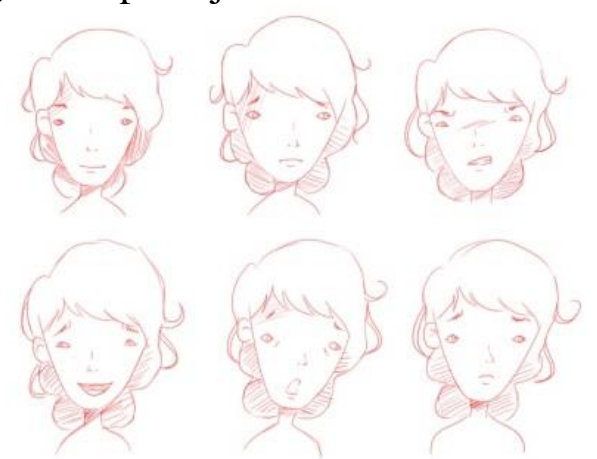

Gambar 4.8 Karakter Ibu

Di samping itu, Ibu sebenarnya terkadang juga merasa lelah dan sering merasa gagal menjadi Ibu yang baik bagi Siene.

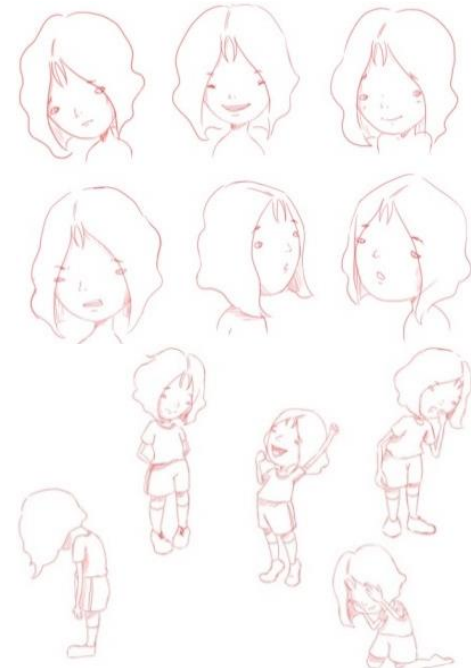

Gambar 4.9 Karakter Siene Kecil

Siene merupakan anak yang memiliki sifat periang, enerjik dan kreatif. Namun kepribadiannya mulai berubah karena terlalu sering menerima hukuman dan tumbuh di lingkungan yang kurang baik. Siene menjadi takut untuk melakukan sesuatu karena takut membuat kesalahan

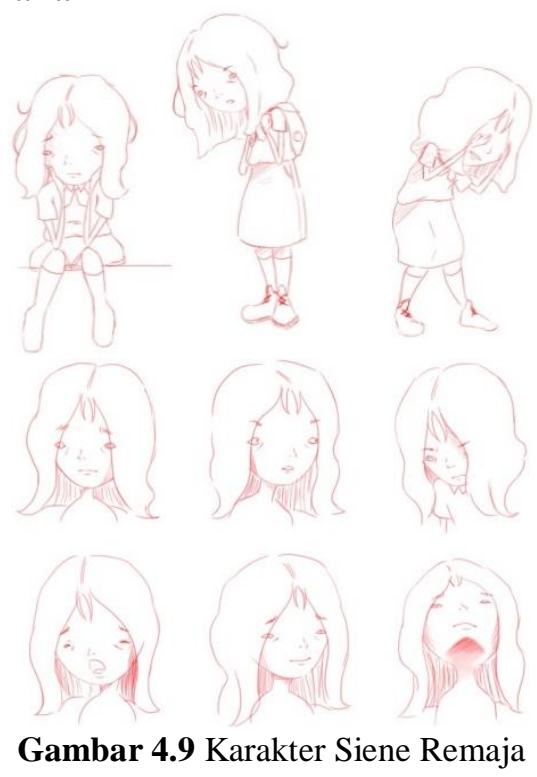

Satu-satunya sosok yang bisa menjadi pelindungnya adalah Ibu. Siene selalu merasa aman dan tenang jika ada Ibu disisinya Seiring bertumbuh, Siene semakin menjadi sosok yang tertutup. Ditambah dengan kematian Ibunya Siene merasa semakin kesepian. Tanpa disadari 
ia telah tumbuh dengan depresi. Siene kerap sulit tidur dan selalu terlihat menyendiri.

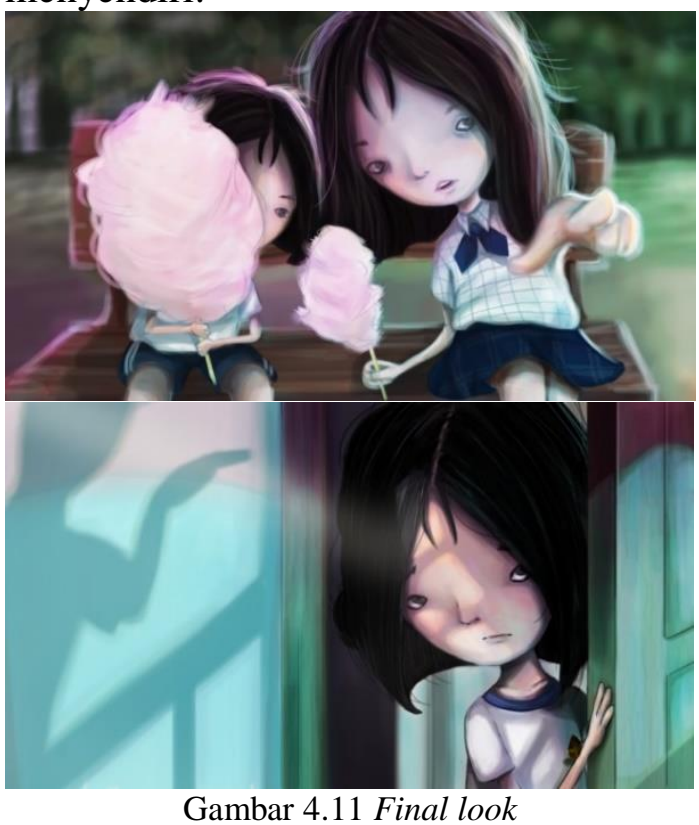

Dalam perancangan animasi ini, penulis mengaplikasikan pewarnaan yang cukup kontras dengan tujuan agar penonton merasakan perasaan yang kurang nyaman. Pengambilan gambar juga menggunakan depth of field pendek sehingga yang terfokus hanyalah pada karakter yang ada. selain itu, penulis juga menerapkan rule od third pada komposisi visual agar pandangan penonton terfokus pada satu arah yang memang dimaksudkan.

\section{SIMPULAN}

Dalam pembuatan sebuah perancangan animasi harus memiliki segala aspek dasar dan data/fakta sebelum mengubahnya dan mengaplikasikannya kedalam sebuah cerita. Karena untuk membuat sebuah film pendek, dibutuhkan pondasi yang kuat. Alasan, target penonton dan kepentingan pembuatannya pun harus diperhatikan. Dalam pembuatan sebuah karya harus mengandung alasan kepentingan / urgent seperti misalnya permasalahan sosial atau konflik yang selama ini ada namun kurang mendapat perhatian masyarkat. Hal-hal seperti itulah yang harus diangkat dan dipublikasikan karena selain menyumbang karya, maka karya itu sendiri memiliki tujuan untuk kepentingan khalayak umum. Dengan alasan itu pula lah dibutuhkan adanya riset untuk memenuhi data-data yang dibutuhkan agar tidak asal mempublikasikan data yang tidak valid. Pada proses perancangan ini, penulis sendiri melakukan riset literatur dan melakukan wawancara pada ahli sehingga informasi tersebut dapat dipertanggung jawabkan dan dapat dipakai sebagai landasan baik cerita maupun karakter. Ide utama cerita ini sendiri berasal dari keresahan penulis akan maraknya peristiwa bunuh diri. Kejadian yang sangat disayangkan, dan menimpa seluruh lapisan masyarkat yang disebabkan oleh tekanan dan kekecewaan. Kejadian yang seharusnya bisa ditangani dan tidak diselesaikan secara demikian jika penderita mendapat pertolongan yang tepat dan mau berbicara pada orang yang tepat.

\section{DAFTAR PUSTAKA}

\section{Sumber Buku}

Ambrose, G. dan Harris, P. (2015). Design Thinking for Visual Communication. London: Bloomsbury Publishing Plc.

Amda, K., \& Fitriyani, R. (2016). Membaca ekspresi wajah. Depok: Huta Publisher

Ashby,F.G., Isen, A.M. \& Turken,A.U. (1999). A neuropsychological theory of positive affect and its influence on cognition. Karya Tulis Ilmiah, 106, 529-550. 
Beane, A. (2012). 3D Animation Essentials. Ottawa: John Wiley\& Sons,Inc.

Besen, E. (2008). Animation Unleashed. California : Michael Wiese Production.

Braembussche, Antoon.V.D. (2006). Thinking Art: An Introduction to Philosophy of Art. Brussels: Springer

Depanfilis, D., \& Salus, M. K. (1994). Coordinated response to child abuse and neglect: A basic manual. Virginia, VA: The Circle

Hodgkinson, G.F. (2007). Visually Representative Web History Browser. Master Tesis. Massey University Wellington: 20

Hodgkinson, G.F. (2012). Story-building techniques for animation using the power of symbolism and semiotics to increase narrative depth and meaning. Karya Tulis Ilmiah, Melbourne: 3-4.

Hallas, J. \& Manvell, R. (1973). The Technique of Film Animation. London; Hastings House.

Lawant, A.B.V. (2011). The Animated Index, The different semiotic Ontologies of the Animation Styles. Tesis Fakultas Kemanusiaan, Utrecht University: tidak diterbitkan.

Rowe, D. (2011). Depression : The Way Out of Your Prison. New York : Routledge
Tickle, N. R. (2015). Cara cepat membaca wajah. (K. Dewi, Trans). Jakarta Selatan: Ufuk Publishing House. (Original work published 2003)

White, T. (2009). How to Make Animated Film. Oxford : Focal Press.

\section{Sumber Internet}

Animation Mentor (2014), Lighting and color in animation films, diakses 07 Januari 2016 dari http://blog.animationmentor.com/ lighting-and-color-in-animationfilms/

Smith, M. \& Segal, J. (2016). Depression Symptoms and Warning Signs, diakses 20 September 2016 dari http://www.helpguide.org/articles /depression/depression-signsand-symptoms.htm

World Health Organization, World suicide prevention day 2012, diakses pada 08 Oktober 2016 dari

http://www.who.int/mediacentre/ events/annual/world_suicide_pre vention_day/en/

World Health Organization, Depression A global Public Health Concern, diakses pada 08 Oktober 2016 dari http://www.who.int/mental_healt h/management/depression/who_p aper_depression_wfmh_2012.pdf 